\title{
Employee Career Development Model Design at PT X
}

\author{
Syaifan Fauzi Nasution ${ }^{1}$, Nazaruddin ${ }^{2}$, Amlys Syahputra Silalahi ${ }^{2}$ \\ ${ }^{1,2}$ Master of Management Study Program on Postgraduate School of University of Sumatera Utara \\ Corresponding Author: Syaifan Fauzi Nasution
}

DOI: https://doi.org/10.52403/ijrr.20220165

\begin{abstract}
Career development is one of the benchmarks for an employee in his career, where performance appraisal is the dominant factor in employee career development at PT. X. In determining the performance appraisal, there are subjective things that become the reference for a superior in giving more assessments to employees.

In this study, the indicators that become the reference for a superior in giving more assessments to subordinates can be used as a reference for an employee in improving his performance. The selected indicators are tested in pairwise comparisons and then processed using the Analytical Hierarchy Process (AHP) method to find out the priority weight of the indicators used by superiors in giving more assessments to their subordinates.

From the results of calculations using the AHP method, the priority order of each component can be obtained, which can then be determined by the highest weight of the indicators used. From the results of calculations using the AHP method, the following priority order can be obtained: Loyalty priority is 0.57 , then Attitude is 0.17 , then Active is 0.11 , Discipline is 0.08 and Honesty is 0.07 . Thus, the factors that require attention and improvement in the performance of an employee are related to loyalty with the highest priority weight gain.
\end{abstract}

Keywords: Attitude, Honesty, Loyalty,

Discipline and Activeness, Career Development, Performance Appraisal, Analytical Hierarchy

Process.

\section{BACKGROUND}

Companies have to be oriented towards career development to face business competition in the future. The existence of future career development depends on human resources because they have to carry out career development for employees which will occur on an ongoing basis. Therefore career development is an activity carried out by Human Resource Management that must be carried out in formal activities and is mutually integrated with other activities.

Career is seen as a continuous learning and development process that is anticipated to increase the acquisition of values that encourage employee development (Gyansah, ST 2018), where career development has various long-term career benefits that help employees to take greater responsibility in the future (Harlie 2012). Promotions provide opportunities for employees to develop forward so that employees become better at completing their responsibilities (Naveed et al, 2011). Career development is a strategic tool for companies to increase productivity, form positive attitudes towards work, and increase satisfaction for all employees (Banu et al, 2009).

Effective career development where a process is always evolving and changing based on the flexibility of a company where career development is not fixed or static and must be reviewed on an ongoing basis and modified continuously. As time goes by there is a change in the existing career system at PT. X, where this change greatly 
affects the career advancement experienced by employees, previously the employee career provisions were more dominantly determined by superiors but now the role of employees is very important for their career development.

The career appraisal system at PT. $\mathrm{X}$, employees must have their strategy on how to make the career path that will be passed run well and meet the career score that has been set by the company, so that every time the transfer is not constrained by a career score that is not enough in its time.

The provisions of the career score system that have been set at this time there are quite significant changes from the previous system, where the certainty of employee career advancement becomes more certain with clearer and more objective references, but as well as the system made by the company there are still gaps where an employee can be left behind in his career if he cannot meet the career score determined by the company and there are still employees who are still at the staff/senior staff level before retirement. References in career advancement already exist, with these career guidelines, employees will make it easier for employees to improve their career paths based on the assessment indicators contained in the guide. However, in reality, there are still many employees whose career level is still in a position that can be at a higher level than the level currently running by the employee.

Based on the job analysis conducted at PT X, there are still many employees whose level of position is still not appropriate, especially at the level of low management and middle management positions with the tenure and level of position that should be obtained at this time. For example, in 2010, employee A should have held the position of Analyst but until 2020 still serves as a Junior Analyst. This makes it clear that there are problems that occur why there are still many employees who are not at the level of the position because their career scores are not met in each period of promotion to the level of office.

However, of all the programs made by the company, other things become a benchmark for a superior when giving more assessments to his subordinates, this will be explored further so that it can be a benchmark for an employee to work and act better, as well as motivation an employee in providing the best results and actions to be given more value.

It is hoped that by using the Analytical Hierarchy Process (AHP) method, various other indicators can be traced that can be a reference for every employee to improve their performance by the expectations of the leadership and the company.

\section{Employee Career Development}

Career development is very important for an employee who becomes a person's work history or stages of positions that have been held while working in a company. Career development is also a sequence of promotions or transfers to other positions or positions that are more in need of more responsibilities or to better places in career advancement while working in a company. The following describes the meanings of careers based on several experts, including:

According to Marwansyah (2015), there are two thoughts about a career, one perspective, a career is a series of jobs that a person undertakes during his life which is called an objective career. Meanwhile, from another perspective, a career includes changes in values, attitudes, and motivations that occur with increasing age which are called subjective careers. Both of these perspectives place a focus on the individual. Both also assume that people have control over their destiny so that they can take advantage of opportunities to maximize the success and satisfaction of their careers. 


\section{Analytical Hierarchy Process (AHP)}

AHP is a method for weighting the performance hierarchy for each KPI that has been obtained (Akbar \& Suliantoro, 2014). In the AHP the criteria can be arranged in a decision hierarchy structure (Wicaksono, Suliantoro, \& Sari, 2010). To get perspective weights and KPIs based on the preferences of decision making on the importance of each perspective, metric group, and KPI using the AHP method (Prastika, Mubin, \& Dewi, 2015). AHP method complex problems can be described in groups and arranged into a hierarchy so that the problem is more structured. In principle, AHP assigns a priority value to each criterion. In making decisions, it is obtained from priority indicators that are considered the biggest priority or contribution (Amelia, 2013).

\section{Key Performance Indicator (KPI)}

Key Performance Indicator (KPI) is a financial or non-financial matrix that is used to help companies measure and determine improvements to company goals (Pratiwi, 2009). According to Moeheriono (2014), KPI is an indicator used to know how far the strategy that has been carried out by the organization or company is by the company's vision and mission. KPI is used to measure the success of performance (Vany \& Tanukhidah, 2004). In assessing activities that are difficult to measure such as profit, development, leadership, agreement, service, and satisfaction, KPIs can be used and are generally associated with organizational strategy (Pratiwi, 2009).
The KPI components will differ depending on the nature and strategy of the organization. KPI itself is a key part of measurable targets in which there are directions, performance indicators, benchmarks, targets, and time frames (Pratiwi, 2009).

Research conducted by eligible (2018) entitled A gray analytic hierarchy process approach to project manager selection, where this study aims to examine the gray analytic hierarchy process approach for project manager selection, the results of which show the application of the proposed approach to gray systems. and fuzzy which includes various units and data. In particular, a system with missing information that has only a range with no other information can be easily interpreted using the proposed $\mathrm{G}-\mathrm{AHP}$.

Another study conducted by Ramhiman, Habeeb UR (2017) entitled Impact Of Employee Work-Related Attitudes on Job Performance examined the impact of employee work-related attitudes on work performance where the results showed a significant and positive relationship between work attitudes (job satisfaction, commitment, leadership). organization and work engagement) and work performance in the health sector. where the findings of this study indicate that, although employee performance and the four dimensions namely; Work attitude, job involvement, job satisfaction, job leadership, and commitment are different they are closely related and influence each other.

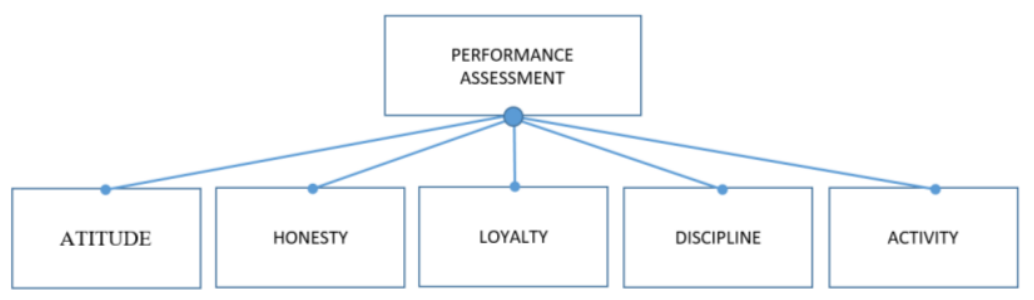

Figure 1. Conceptual Framework

Then the Process Hierarchy Analysis (AHP) was carried out on the indicators above so that the most important indicators or those with the highest weights were used as a reference to achieve the goals, namely the new indicators that became the reference for performance assessment to improve employee performance and as a Design 
Model for Employee Career Development at PT. X.

\section{RESEARCH METHOD}

This research uses the Analytical Hierarchy Process (AHP) method. The analysis results obtained are the bestranking order, resulting in the criteria with the highest weights that can be used as considerations in giving more assessments to employees and making decisions in detail about the Planning of Employee Career Development Models at PT.X. This research was conducted at PT. X regional 1, where this research was conducted from May to July 2021 and required an effective period of 12 (twelve) weeks.

This study does not use the term population but uses a social situation that consists of three elements, namely: place (place) which is carried out at PT. X, the actors (actors) employees at PT. X and the activity is doing a KPI assessment. Where the sample in this study is called the resource person, namely people who are considered experts and have certain responsibilities, in this study the author uses employees who have subordinates in the $\mathrm{R}$ Division at PT. $\mathrm{X}$ has the responsibility to provide performance appraisals to his subordinates.

Primary data is data obtained directly from the source. The data was obtained from the PT.X expert who understands the problems that occur in the company. The selection of experts is based on years of service, free time, knowledge of employee performance appraisal issues, and having subordinates. The primary data used in this study is data regarding the performance of the $\mathrm{R}$ Division obtained through interviews, a list of questions, and brainstorming with the coordinator under Division R. Secondary data is data obtained indirectly, and the source itself is obtained from several PT.X documents, literature studies such as journals, books, and the internet. The nature of secondary data itself is to support the needs of primary data.

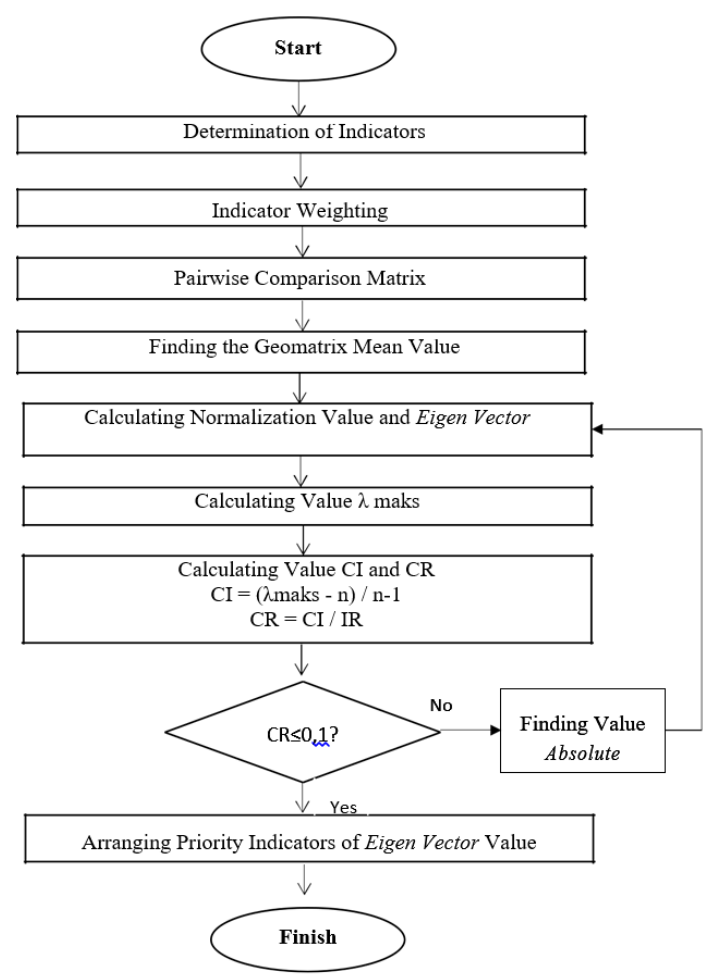

Figure 2. Flowchart AHP Program

\section{RESULT AND DISCUSSION}

From the results of interviews and comparison questionnaires as well as the calculation of priority weights using the Analytical Hierarchy Process (AHP) method, it was obtained 5 indicators that became a reference for a superior in giving more assessment to subordinates in Division $\mathrm{R}$, PT. X. Where the indicators include: Loyalty, Attitude, Activeness, Discipline and, Honesty. Where the highest weight on the five indicators is the Loyalty indicator of 0.57 .

Loyal is meant by the resource persons in this study not seeking excessive attention to superiors, but what is meant by loyal here is how an employee can help the team to move forward together - together advancing the company and its team.

In the performance appraisal system at PT. Currently, the indicators that are used as references in this performance assessment have not been included in the existing Key Performance Indicator (KPI) performance appraisal system, so that a superior can use the AHP method in providing more assessments to subordinates 
so that when giving an assessment the approach is more objective.

When compared with previous research conducted by lhami (2017), which examined Employee Performance Assessment with the AHP Method and Rating Scale, where the results of this study indicate that the performance appraisal of junior analysts at the PT.X Routine Testing Laboratory Department considers 8 (eight) things., namely attendance, achievement of work targets, work thoroughness, proactiveness, empathy, cooperation, analytical thinking, and flexibility. Where the highest weight is found in the achievement of work targets with a weight value of 0.124 .

In a company, each boss has a different character as well as the field of work, so each boss or field of work has a different assessment reference following the character and needs of the field of work. To obtain more optimal results, the use of this AHP method should focus on one resource person who has the responsibility to provide assessments to certain parts of a company due to differences in research objects in the form of characters and fields of work as improvements in subsequent research.

The indicators obtained can be used as a reference for an employee in developing themselves and improving their performance so that they become motivated in planning employee career development at PT. X, for example by proposing soft skills training and building two-way communication between superiors and subordinates so that a harmonious and productive work environment is built.

In addition to being used by employees who do not have subordinates, the indicators obtained from this research can also be used as a reference for a superior in improving the performance of his team, one of which is by doing Coaching, Mentoring, and Counseling (CMC) periodically, Miller and More (2014) in their book that entitled Effective Police Supervision said that the provision of training, coaching, mentoring and counseling is a way that a superior can use to help employees grow and develop properly. It is hoped that this research, can make references to companies, both superiors and employees alike, to improve their performance and can become a Planning Model for Employee Career Development at PT. X.

\section{CONCLUSION}

1. Indicators that become a reference for a superior in providing more assessment to subordinates at PT. X is Loyalty, Attitude, Activeness, Discipline, and Honesty, with the highest value weighting on the Loyalty indicator with a value of 0.57 .

2. The matrix value used is the geometric average matrix value obtained from several sources, where the results of this calculation show that the weighting value from the largest to the smallest is as in point 1 above, but it is likely that the amount of weight is different from one source to another. others, if simulated using the results of a comparison matrix from each resource person, it is necessary to focus on determining the value of the matrix for each section according to the resource person or person in charge of the employee's job appraisal to get the highest amount of weight according to the person in charge who assesses in each section.

\section{Acknowledgement: None}

\section{Conflict of Interest: None}

\section{Source of Funding: None}

\section{REFERENCES}

1. Akbar, M. R. (2014). Analisis pengukuran kinerja produksi menggunakan metode sink's seven performance criteria pada departemen produksi mesin ps60 pt. General electric indonesia. Semarang: Industrial engineering online journal.

2. Alif, A. (2015). Pengaruh Motivasi Kerja, Pengembangan Karir Dan Lingkungan 
Kerja Terhadap Organizational Citizenship Behavior (Ocb) Dengan Kepuasan Kerja Sebagai Variabel Intervening Pada Perusahaan Terminal Lpg. Jurnal MIX, Volume VI, No. 2, 291-309.

3. Alonso, J. A. (2006). Consistency in the analytic hierarchy process: a new approach. International journal of uncertainty, fuzziness and knowledge-based stem. 445-459.

4. Amelia, L. (2013). Perancangan sistem pengukuran kinerja di fakultas teknik universitas.

5. Universitas Esa Unggul Jakarta Jurnal Inovasi.

6. Arum, \& Handayani, N. ( 2013). Penerapan Metode Balanced Scorecard Sebagai. Jurnal Ilmu \& Riset Akuntansi, Vol. 2 No 2.

7. Bianca , O. C. (2016). Pengaruh Gaya Kepemimpinan Dan Motivasi Kerja Terhadap Kinerja Karyawan Pada CV. Karya Hidup Sentosa. Universitas Negeri Yogyakarta, Yogyakarta.

8. Celikbilek, Y. (2017). A grey analytic hierarchy process approach to project manager selection. Journal of Organizational Change Management, 18-54.

9. Gyansah, S. T. (2018). Placing the Organization and the Employee on the Same Pedestal to Enhance Maximum Productivity. Career Development in Organizations, 40-45.

10. Handika, F. S., Setyanto, N. W., \& Efranto, R. Y. (2013). The Using Of Balanced Scorecard Method To Improve Company's Performance Based on Analytical Hierarchy Process And Objectives Matrix (Case Study: PT. Bank X (Persero) Tbk. Malang). Universitas Brawijaya, 144-155.

11. Handoko, T. H. (2015). Manajemen. Yogyakarta: BPFE.

12. Harlie, M. (2012). Pengaruh Disiplin Kerja, Motivasi dan Pengembangan Karier Terhadap Kinerja Pegawai Negeri Sipil Pada Pemerintahan Kabupaten Tabalong di Tanjung Kalimantan Selatan. Jurnal Manjemen dan Akuntansi Vol 11 No.2, 117124.

13. Ilhami, R. S. (2017). Penilaian Kinerja Karyawan dengan Metode AHP dan Rating Scale.Jurnal Optimasi Sistem Industri, 50157.

14. Keith, D. (1985). Perilaku dalam Organisasi. Jakarta: Erlangga.
15. Mangkunegara, A. P. (2001). Manajemen Sumber Daya Manusia. Bandung: Remaja Rosdakarya.

16. Mangkunegara, A. P. (2015). Sumber Daya Manusia Perusahaan. Bandung: Remaja Rosdakarya.

17. Mardjuki, T., \& S, P. (2006). Analisa Kinerja Departemen A Pada Divisi Manufaktur di PT. X Menggunakan Kerangka Balanced Scorecard. Prosiding Seminar Nasional Manajemen Teknologi III (hal. A-15-2). Surabaya: Program Studi MMT-ITS.

18. Marwansyah. (2015). Manajemen Sumber Daya Manusia. Jakarta: Alfabeta.

19. Mathis, R. L., \& Jackson, J. H. (2011). Human Resource Managemen. USA: SouthWestern Cengage Learning.

20. Moeheriono. (2014). Pengukuran Kinerja Berbasis Kompetensi Edisi Revisi. Jakarta: PT RajaGrafindo Persada.

21. More, H. W., \& Miller, L. S. (2014). Effective Police Supervision. London and Newyork:Routledge.

22. Nasution, H. (2008). Proses Pengelolaan Sumber Daya Manusia. Medan: USU Press.

23. Naveed et al. (2011). Effect of Transformational Leadership on Employees' Job Satisfaction and Organizational Commitment in Banking Sector of Lahore (Pakistan). International Journal of Business and Social Science, 263-267.

24. Ningsih, R. D., Setyanto, W. N., \& Arif, R. (2014). Designing A Performance Measurement System Production Unit of Rice Seed And Crops Using Sink's Seven Performance Criteria Model. 67-79.

25. Nitisemito, A. (2016). Manajemen Sumber Daya Manusia. Bandung: Pustaka Setia.

26. Onsardi. (2018). Employee Loyalty In Private University In Bengkulu City. Bengkulu: https://doi.org/10.31539/costing.v2i1.326.

27. Prastika, V. R., Mubin, A., \& Dewi, S. K. (2015). Peningkatan Kinerja Perusahaan Kemasan Plastik Dengan Pendekatan Metode Performance Prism Dan Objective Matrix. Simposium Nasional Teknologi Terapan (SNTT), 77-78.

28. Pratiwi. (2009). Analisis Faktor Karakteristik Individu Yang Berhubungan Dengan Tindakan Tidak Aman Pada Tenaga Kerja Di Perusahaan Konstruksi Baja. 182191. 
29. Rahman , A. (2008). Penentuan Kriteria Yang Paling Berpengaruh Terhadap Prestasi Kerja Karyawan Di Cv. Rimba Sentosa Sukoharjo. Surakarta: Universitas Muhammadiyah Surakarta.

30. Rahman, H. U. (2017). Impact Of Employee Work-Related Attitudes on Job Performance.British Journal of Economics, Finance and Management Sciences, 94-105.

31. Rivai, \& Sagala, E. (2015). Manajemen Sumber Daya Manusia Untuk Perusahaan. Jakarta: Rajawali Pers.

32. Rusyan , A. T. (2006). Pendidikan Budi Pekerti. Jakarta: Sinergi Pustaka.

33. Sinulingga, S. (2015). Metode Penelitian. Jakarta: USU Press.

34. Sugiyono. (2017). Metode Penelitian Kualitatif. Jakarta: Alfabeta.

35. Sulisworo, D. \&. (2011). Pembobotan Sasaran Strategis Perspektif Balance Scorecard (Bsc) Pada Perusahaan Air Minum. Jurnal ilmiah teknik industri, 22-28.
36. Sutrisno, E. (2016). Manajemen Sumber Daya Manusia. Jakarta: Kencana Prenada Media Group.

37. Vanany, I. \&. (2004). Perancangan Dan Implementasi Sistem Pengukuran Kinerja Dengan Metode Performance Prism. Jurnal Teknik Industri, 148-155.

38. Widodo, E. S. (2015). Manajemen Pengembangan Sumber Daya Manusia. Yogyakarta: Pustaka Pelajar.

39. Wirawan, R. B. (2014). Penentuan Prioritas Investasi Bidang Teknologi Informasi Menggunakan Metode Fuzzy-Multi Criteria Decision Making (Studi Kasus Politeknik Caltex Riau). Seminar nasional teknologi informasi dan komunikasi 2014 (sentika 2014), 106-115.

How to cite this article: Syaifan Fauzi Nasution, Nazaruddin, Amlys Syahputra Silalahi. Employee career development model design at PT X. International Journal of Research and Review. 2022; 9(1): 561-567. DOI: https://doi. org/10.52403/ijrr.20220165 